\title{
Determinants of Profitability of Polish Banks: The Role of Foreign Banks
}

\author{
Małgorzata Pawłowska*a \\ *Szkoła Główna Handlowa w Warszawie and Narodowy Bank Polski, \\ Economic Institute
}

Submitted: January 26, $2016 \bullet$ Accepted: April 21, 2016

\begin{abstract}
The aim of this study is to examine the effect of bank-specific and macroeconomic determinants of bank profitability in Poland using an empirical framework that incorporates the traditional Structure-Conduct-Performance (SCP) hypothesis as well as the Relative Market Power (RMP) hypothesis. This paper also examines the overall effect that financial structure and macroeconomic conditions had during the global financial crisis of 2008. Finally, this paper tests the effect of foreign capital on the profitability of Polish banks and attempts to determine if there is a link between the context of the parent banks and the profitability of their affiliates during the global financial crisis of 2008 and the debt crisis in the Eurozone. Empirical results based on panel data sets containing both micro-level and macro-level data are ambiguous, and we found evidence of the RMP hypothesis only. Furthermore, this paper found a positive correlation between the context of parent banks and the profitability of their affiliates. Finally, we determined that the profitability of commercial banks in Poland was contingent upon the business cycle.
\end{abstract}

JEL classification: F36, G2, G21, G34, L1

Keywords: bank profitability, market power, market structure, Polish banks, foreign banks, business cycle

*Corresponding Author. Email: mpawlo1@sgh.waw.pl 


\section{Introduction}

The profitability of banks is a subject of great interest in bank management, financial markets, bank supervision, and academics. This interest is driven by increasing globalization and consolidation within the banking sector. Globalization is changing the ownership structure of banking sectors around the world, and the Polish banking sector is no exception. Foreign banks may not only enhance the availability of credit by directly lending to domestic firms or households, but they may also increase competition between banks. Furthermore, in many countries (including Poland), we observed an increased trend toward bank disintermediation.

Currently, the profitability of commercial banks in Poland is influenced by a large number of internal and external factors: consolidation, technological processes, changes in regulation, and the real economy. However, the Polish banking sector is relatively small in comparison to the other countries in the European Union (EU) because it is only worth $85 \%$ of the country's GDPand has relatively simple, traditional business models that are dominated by foreign banks. ${ }^{1}$ As of the end of 2012, the share of banks with predominantly foreign capital was approximately $65 \%$ whereas it was approximately $15 \%$ at the end of 1997 (cf., Figure 1). The parent financial institutions of Polish banks were located mostly in Western Europe (Austria, Belgium, Greece, Germany, France, Italy, Netherlands, Portugal, and Spain) and in the United States (cf., Figure 2). Finally, the financial crisis and the increase in systemic risk associated with cross-border links between large banks gave rise to activities aimed at reforming the post-crisis institutional system, and this reform included the systemically important banks (G-SIFIs). The fact that some of the banks on the list of G-SIFIs are also parent banks of Polish banks is significant for their affiliates (e.g., Unicredit Group and Crédit Agricole Group are parent banks in the Polish banking sector). ${ }^{2}$

The aim of this study is to estimate the effect of market structure on the performance of banks in Poland during the financial crisis of 2008 - after the Lehman Brothers failure. This paper will also examine the overall effect of financial structure and macroeconomic conditions to determine whether financial development and business cycles affect the profits of Polish banks. Finally, this paper attempts to determine if there is a link between the context of parent banks and the profitability of their affiliates.

In order to test the traditional Structure-Conduct-Performance (SCP) hypothesis, this paper empirically investigates the effect of market structure as it relates to profitability and has a particular focus on whether banks that are operating in concentrated markets generate more profit or not. Aside from the traditional SCP hypothesis, this paper also tests the Relative Market Power (RMP) hypothesis created by Smirlock (1985). Smirlock posited that

\footnotetext{
${ }^{1}$ The average for EU-27 countries is about $400 \%$ (e.g., Bijlsma and Zwart, 2013; Polish Financial Supervision Authority, 2013).

${ }^{2}$ Criteria for the designation of G-SIFI's: size and international link, lack of readily available substitutes for services provided or adequate infrastructure for services, global activity (i.e., activity in many legal jurisdictions), and complexity of the activity (i.e., its effect on the financial system and the economy).
} 
there is no relationship between concentration and profitability but that there is a relationship between a bank's market share and its profitability.

In order to carry out a quantitative assessment of the effect of market structure on banking performance, this study uses panel data sets to combine micro- and macro-statistical data covering cyclical factors and the macroeconomic environment. Panel data consisted of quarterly micro- and macro-level data, combining data for Polish commercial banks and their parent banks, and information about the macroeconomic environment for the period of 2007Q1-2013Q2. We received micro-level data for Polish commercial banks from the National Bank of Poland (balance sheets, profit and loss accounts), and we received micro-level data for their parent banks from the Bankscope database. ${ }^{3}$ We received macroeconomic data from the Polish Central Statistical Office (CSO) and Eurostat. We analysed the change of concentration within the Polish banking industry using the Herfindahl-Hirschman indices (HHI; cf., Figure 3), and we analysed profitability in the Polish banking sector using the return on assets ratios (ROA).

This study's major contribution to the literature is to test the SCP paradigm and the RMP hypothesis in the Polish banking sector and also to examine the role of foreign capital in this context during the crisis. This study consists of two parts and a summary. The first part is a broad literature review concerning the relationship between bank profit and market structure. The second part describes the changes in profitability within the Polish banking sector and presents data, empirical models, and the results of the analysis of panel data for the period 2007Q1-2013Q2. The summary provides an overview of the empirical results and the conclusions that we made.

\section{Relationship Between Bank Profitability and Market Structure}

There have been recent and ongoing debates concerning the economic role of market structure and competition within the banking industry. Developments in the banking sector do not only affect banks, but are highly relevant to the economy as a whole. Accordingly, both the competition between banks and the profitability of the banking sector is of interest not just at the individual bank level, but also at a broader macroeconomic level. Dramatic changes in regulation and technology have modified the structure of the banking sectors. All of these changes have strengthened competition - especially in traditional lending activity - and have encouraged banks to diversify their sources of revenue.

The SCP model was developed by Bain (1951), and this theory states that in a market with higher concentration, banks are more likely to show collusive behaviour and their oligopoly

\footnotetext{
${ }^{3}$ The Bankscope database was created by Bureau van Dijk-Electronic Publishing. It contains information on balance sheets and income statements for commercial banks around the world.
} 
rents will increase their performance (i.e., profitability). The SCP paradigm dominated until the late 1970s, and it assumed that a more concentrated system leads to less competition and therefore higher profitability. Berger (1995) advocated the traditional SCP paradigm where banks set prices that are less favourable to consumers as a result of imperfectly competitive markets. Smirlock (1985) tested an alternative explanation for these results. Specifically, he posited that there is no relationship between concentration and profitability, but rather between bank market share and bank profitability. In making this distinction he created the Relative Market Power (RMP) hypothesis. However, subsequent results of analyses based on the SCP paradigm have shown that the relationship between the structure of the market and conduct is even more complex.

The Efficient Structure hypothesis (ES) was developed by Demsetz (1973), and the ES theory states that if banks enjoy a higher degree of efficiency than their competitors, they can increase shareholder value or gain market share by reducing their prices. According to the ES, concentrated markets are those where highly effective firms (banks) operate. Efficiency is not an effect but a determinant of market structure. However, Hicks (1935) developed a theory opposite to the ES, which is known in literature as the Quiet Life (QL). According to the QL, banks with superior market strength and thus a privileged position will suffer a lower cost efficiency due to the quiet life of their managers. Generally, the QL hypothesis assumes that monopoly will reduce the pressure toward efficiency (cf. Bikker and van Leuvensteijn, 2014).

A number of studies have examined the influence of market structure based on the SCP paradigm, and several of these studies reported a positive relationship between concentration and profitability (e.g., Demirgüç-Kunt and Huizinga, 2000; Molyneux and Thornton, 1992; Goddard et al., 2004), which confirms the traditional SCP hypothesis. However, Mirzaei et al. (2013) and Maudos and De Guevara (2004) also confirmed the RMP in advanced economies. The ES hypothesis, by contrast, was confirmed by Claeys and Vander Vennet (2008). Most of the studies focusing on the macroeconomic influences on bank profitability found that the business cycle had a positive influence on the development of bank profitability and that there was a positive correlation between bank profitability and inflation (e.g., Albertazzi and Gambacorta, 2009; Bikker and Hu, 2002; Demirgüç-Kunt and Huizinga, 2000; Rumler and Waschiczek, 2010).

The majority of the studies analyzing the determinants of banks performance are focused on selected microeconomic factors. The present paper offers a broad view on the subject and takes into account many micro factors as well as cyclical components (cf. Delis et al., 2014). Comprehensive studies describing many micro factors and business cycles have been published for the Austrian banking sector (cf. Rumler and Waschiczek, 2010) and for Greek banks (cf. Athanasoglou et al., 2008).

The relationship between profitability and foreign banks has been analyzed in many papers. However, empirical research on the relative performance of domestic and foreign banks 
has produced ambiguous results, with some studies finding that foreign banks perform better and other studies reporting stronger performance from domestic banks (cf. Degryse and Ongena, 2008; Chen and Liao, 2011). On the one hand, Havrylchyk and Jurzyk (2011) showed that foreign banks (i.e., acquired by foreign investors) in Central and Eastern European countries are more profitable due to cost minimization and better risk management. Van Horen and Claessens (2012), however, found that foreign banks might have higher capital and more liquidity, but they have lesser profitability than domestic banks. Also, during the global financial crisis of 2008, foreign banks reduced credit more sharply when compared to domestic banks, except when they dominated the host banking systems. On the other hand, other researchers have found almost no evidence that the ownership structure of banks had an effect on their profitability (e.g., Molyneux and Thornton, 1992; Cetorelli, 2004). Furthermore, La Porta et al. (2002) concluded that a state bank follows a political rather than a social agenda.

Finally, there are not a lot of studies that take into account the relationship between the profitability of the parent banks and the situation of their affiliates in the context of determining profitability - this paper fills the gap. The paper by Pawłowska et al. (2015) found intragroup links between banking institutions after the Lehman Brothers failure in the Polish banking sector.

\section{Banking Structure, Business Cycle, and Profitability of Banks - Panel Data Analysis}

The profitability of commercial banks in Poland prior to and during the financial crisis was influenced by a large number of internal and external factors: consolidation, technological processes, and the real economy (cf., Figure 4). After Poland's accession to the EU, there was a clear improvement in profitability both with return on assets (ROA) and return on equity (ROE). This improvement in bank profitability was facilitated by, among others, a decrease in the share of non-performing loans in assets. ${ }^{4}$ In 2009, the slight decrease in profitability indicators were caused by the financial crisis (see Figures 5 and 6). It should be noted, however, that the group of Polish commercial banks was not homogeneous during the first part of the crisis. There was a strong deterioration in the financial results of several banks that, in previous periods, were characterized by increasing market shares (particularly in the segment of household loans). These banks had a negative effect on the performance of the entire group (however, some banks reported an improvement in financial results as compared

\footnotetext{
${ }^{4}$ Since Poland's accession to the EU, the classification of non-performing loans become less restrictive. Sub-standard receivables from one to three months changed to three to six months, doubtful receivables from three to six months changed to six to twelve months, and lost receivables from the above six months to the above twelve months. See National Bank of Poland (2004).
} 
to 2008; cf. Polish Financial Supervision Authority, 2010). In the period 2010-2014, the profitability of Polish commercial banks improved again.

\subsection{Data and Model Specification}

In order to test the traditional SCP hypothesis and the RMP hypothesis, as well as the effect of the macroeconomic changes on the profitability of banks in Poland, this study examined quarterly data covering the period of the financial and debt crises (1997Q4-2013Q2). This data was obtained for all commercial banks operating in Poland (i.e., Polish banks, subsidiaries of foreign institutions, and branches of foreign banking institutions $)^{5}$. The panel data sets combined micro-level data for Polish commercial banks and macro-level statistical data covering cyclical factors, and this study used a variety of microeconomic indicators stemming from the bank data to capture changes in the economic framework, including balance sheets and income statement figures from the National Bank of Poland's balance sheet statistics. Additionally, the panel data set consisted of data from the Bankscope database, which is a source of valuable information about the foreign parent institutions of the Polish affiliates. The micro-level data from Bankscope was then merged with data on the Polish banking institutions (cf., Tables 1, 2, and 3). Macroeconomic data on the growth of GDP and inflation in Poland came from the CSO (Central Statistical Office). The panel also included macro-level data from Eurostat concerning GDP growth in the parent banks' countries.

In order to carry out a quantitative assessment of the effect of market structure on the profitability of banks in the Polish sector, the generalized method of moments (GMM) estimator was used. The GMM estimator was proposed by Arellano and Bond (1991) and generalized by Arellano and Bover (1995) and Blundell and Bond (1998). ${ }^{6}$ This paper used the system GMM (xtabond2) procedure, which can fit two closely related dynamic panel data models (the Arellano-Bond estimator and the Arellano-Bover estimator, fully developed in Blundell and Bond, 1998). The original estimator is sometimes called difference GMM, and the augmented one is sometimes called system GMM. However, the xtabond2 procedure implements both estimators. As GMM estimators, the Arellano-Bond estimators have one- and two-step variants (Arellano and Bond, 1991; Blundell and Bond, 1998). However, using the two-step GMM estimator may impose a downward (upward) bias in standard errors (t-statistics) due to its dependence on the estimated residuals. This may lead to unreliable asymptotic statistical inference (Bond and Windmeijer, 2002; Bond, 2002; Windmeijer, 2005), especially in data samples with a relatively small cross section dimensions (Arellano and Bond, 1991; Blundell and Bond, 1998). However, the xtabond2 procedure uses a finite-sample correction to the two-step covariance matrix derived by Windmeijer (2005).

\footnotetext{
${ }^{5}$ The numbers of banks fluctuated in the sample due to acquisitions, liquidations, and new banks entering the market.

${ }^{6}$ Use of a GMM estimator also accounts for possible correlations between any of the independent variables.
} 
Finally, taking into account the above factors, this paper used a two-step robust estimator with a correction derived by Windmeijer (2005). ${ }^{7}$ Moreover, we used the Hansen test of overidentifying restrictions, which tests the overall strength of the instruments for a one step estimator (Arellano and Bond, 1991; Arellano and Bover, 1995; Blundell and Bond, 1998), and we used the Arellano-Bond tests for $\mathrm{AR}(1)$ and $\mathrm{AR}(2)$ in the first differences. We also performed model estimation separately to avoid any alignment of variables. In order to solve the problems arising from extreme outliers that affect estimation, all outliers were removed from each panel data set (i.e., any value below the first percentage point or above the $99^{\text {th }}$ percentage point in sample distributions was removed).

\subsection{The Baseline Model and Estimation (Quarterly Data Set Dur- ing the Global Financial Crisis and Eurozone Debt Crisis)}

In order to carry out a quantitative assessment of the effect of banking sector structure on banking profitability in the Polish sector during the crisis, a quarterly data set was used that was based on data from 2007Q4-2013Q2.

The following baseline model with ROA as the dependent variable was calculated as follows:

$$
\begin{aligned}
R O A_{i, t} & =\alpha+a_{0} R O A_{i, t-1}+a_{1} \text { market structure }{ }_{i, t}+a_{2} \text { market }_{\text {power }}{ }_{i, t} \\
& +a_{3} \text { business cycle }_{i, t}+a_{4} F O_{i}+a_{5}\left(C R I_{t} \times F O_{i}\right)+a_{6} \text { EuDCRI }_{t} \\
& +\sum_{j=1}^{N} b_{j} \text { ot }_{i, t}+\varepsilon_{i, t}
\end{aligned}
$$

where $R O A_{i, t}$ denotes the return on assets ratio for each bank $i$ and for each quarter $t{ }^{8}$ The market structure measure was defined as follows:

- The concentration ratio such as the Herfindahl-Hirschman index for assets $\left(H H I_{t}\right)$ for each quarter $t$.

In this model, the size of the banking sector was defined as follows:

- The log of total assets where the total assets are the sum of assets of all banks $\left(S_{\left.i z e_{t}\right)}\right.$ for each quarter $t$ (cf., Figure 7).

Market power, the relative measure of market power, was defined as follows:

\footnotetext{
${ }^{7}$ In the estimations, we used lagged dependent variables as instruments.

${ }^{8}$ To determine the robustness, additional estimations were calculated with the return on equity (ROE) for each banking sector i for each year $t$ as a dependent variable. The results were very similar.
} 
- The share of bank assets in the total assets $\left(M P_{i, t}\right)$ for each bank $i$ and each quarter $t$.

- The share of bank loans in the total loans $\left(M L_{i, t}\right)$ for each bank $i$ for each quarter $t$ (cf., Figure 8).

Also, as the measure of relative market power, the model also tested the affect of the size of the bank on profitability, which was defined as follows:

- The log of total assets $\left(L A_{i, t}\right)$ for each bank $i$ for each quarter $t$.

The model also estimated the dummy variables indicating foreign ownership as follows:

- The dummy $\left(F O_{i}\right)$ that takes the values of one if a bank is foreign-owned, and takes a value of zero elsewhere for each bank $i$ for each quarter $t$.

This model also controls for the effect of the global financial crisis and the Eurozone debt crisis in relation to profitability and foreign ownership. Therefore, other control dummy variables were used in regression as follows:

- The dummy variable $\left(C R I_{t}\right)$ that takes the value of one if $\mathrm{t}<2010 \mathrm{Q} 3$ and $\mathrm{t}>=2008 \mathrm{Q} 4$, and zero elsewhere.

- The dummy variable $\left(E u D C R I_{t}\right)$ that takes the value of one if $\mathrm{t}>=2010 \mathrm{Q} 3$ and zero elsewhere.

Therefore, the full sample was split into three intervals: (1) the global financial crisis, (2) the Eurozone debt crisis (the sample begins in 3Q 2010 and ends in 2Q 2013), and (3) the whole analyzed period (2007Q4-2013Q2).

The model also tests the effect of the business cycle on bank profitability during the crisis. The variable business cycle was defined as follows:

- $G D P_{t}$ growth (yoy) and inflation growth $\left(C P I_{t}\right)$ for each quarter $t$.

In regressions, we also used control variables $\left(o t h_{i t}\right)$ :

- The ratio of total deposit to total assets $\left(D T A_{i t}\right)$ for each bank $i$ for each quarter $t$.

- The ratio of total loans to total assets as a measure of the magnitude of disintermediation tendencies $\left(L T A_{i, t}\right)$ for each bank $i$ for each quarter $t$.

- The core capital ratio $\left(C A R_{i, t}\right)$ as an indicator of a bank's risk behavior (the higher the capital ratio, the greater the risk aversion) for each bank $i$ for each quarter $t$. 
- The share of foreign currency housing loans to the household sector in total loans $\left(F X H L_{i, t}\right)$ as an indicator of banking sector development for each bank $i$ for each quarter $t$.

The parameter $\alpha$ is a constant term, $\varepsilon_{i, t}$ denotes the error, and $a_{0}, a_{1}, a_{2}, a_{3}$, and $b_{j}$ are the regression coefficients.

Table 4 presents the results of regressions using a two-step GMM estimator. For each of the estimations, we also reported the Hansen test results at the bottom of the table as well as the Arellano-Bond tests $(\mathrm{AR}(1)$ and $\mathrm{AR}(2))$. The model seemed to fit the panel data reasonably well, as the Hansen-test showed no evidence of over-identifying restrictions.

In Table 4, a positive coefficient $a_{1}$ was found only in regression 3. However, a positive and significant coefficient $a_{1}$ was found for the variable Size $e_{i, t}$. Also, a positive and significant coefficient $a_{2}$ was found for relative size $\left(L A_{i, t}\right)$ in regressions $2-4$.

Relative market power - measured in terms of the individual institution's share in total assets $\left(M P_{i, t}\right)$ - had a positive and significant influence on the profitability indicators in this study. However, relative market power - measured in terms of the individual institution's share in total domestic lending $\left(M L_{i, t}\right)$ - had no significant influence on the profitability indicators in this study.

This paper also found a positive effect for foreign capital on profitability during the period of the Eurozone debt crisis (estimation 5). However, for the period of global financial crisis, this paper found a negative effect for foreign capital on the profitability of Polish banks (estimations 3 and 4). Finally, this paper found a positive correlation between the context of parent banks and the profitability of their affiliates for the entire period analyzed.

Of the microeconomic control variables, we found the ratio of the core-capital to riskweighted assets to have a significant and negative influence on bank profitability. We found that banking sector development - measured in terms of foreign currency lending - had a significant and negative influence on bank profitability. These findings indicate that foreign currency loans did not positively contribute to bank profitability. They also show the positive correlation between intermediation (i.e., grater loans in total assets) and bank profitability. However, our results show a negative coefficient between the ratio of total deposit to total assets and profitability.

Generally, this paper found positive correlations between GDP growth and inflation $(C P I)$, and the profitability of banks throughout the entire period of analysis. This means that the profitability of banks is procyclical.

In addition to all these estimated results, this paper found evidence for RMP hypothesis. However, this paper did not find sufficient evidence to verify the SCP hypothesis. 


\subsection{Effect of Parent Bank Situation on Profitability of their Affil- iates}

Furthermore, this paper tested the effect of the parent bank condition on the profitability of their affiliates. In this case, we estimated additional regressions using the GMM estimator. The ROA of banks with a majority of foreign capital was used as the dependent variable in this model. Independent variables were taken from Bankscope and from Eurostat, and the following model with ROA as the dependent variable was calculated as follows:

$$
\begin{aligned}
R O A f_{i, t} & =\alpha+a_{0} R O A f_{i, t-1}+a_{1} \text { business cycle in parent country } y_{i, t} \\
& +\sum_{j=1}^{N} b_{j} \text { ot } h_{i, t}+\varepsilon_{i, t}
\end{aligned}
$$

where $R O A f_{i t}$ denotes the return on assets ratio for each bank with a majority of foreign equity $i$ for each quarter $t$.

This model tested the effect of business cycles in the parent country on foreign bank profitability during the crisis. The variable business cycle was defined as GDP growth in the parent country, and the measure of this growth was taken from Eurostat (parent_GDP) for each bank with a majority of foreign equity $i$ for each quarter $t$.

In regressions, we used the following control quarterly variables $\left(o t h_{i t}\right)$ from the Bankscope database:

- parent_Total_Capital_Ratio - The capital ratio of foreign parent institutions of Polish affiliates for each bank with a majority of foreign equity $i$ in each quarter $t$.

- parent_Net_Loas_to_Assets - Net loans to assets ratio of foreign parent institutions of Polish affiliates for each bank with majority of foreign equity $i$ for each quarter $t$.

- parent_ROA - ROA ratio of foreign parent institutions of Polish affiliates for each bank with a majority of foreign equity $i$ for each quarter $t$.

The variable $\alpha$ is a constant term, $\varepsilon_{i t}$ denotes the error, and $a_{0}, a_{1}$, and $b_{j}$ are the regression coefficients.

We constructed three regressions for three time periods: (1) the global financial crisis, (2) the Eurozone crisis of 2011-2012 (the sample begins in 3Q 2010 and ends in 2Q 2013), and (3) the entire period (2007Q4-2013Q2).

Table 5 presents the results of regressions using a two-step GMM robust estimator. For each estimation, we reported the Hansen test results at the bottom of the table as well as the Arellano-Bond tests $(\mathrm{AR}(1)$ and $\mathrm{AR}(2))$. The model seems to fit the panel data reasonably well because the Hansen-test shows no evidence of over-identifying restrictions. 
Table 5 reports the positive coefficient $\left(\mathrm{a}_{1}\right)$ (estimations 1 and 2). This means that GDP growth in the parent country of a bank operating in Poland has a significant and positive effect on its profitability in Poland for the entire period of analysis and also for the period of the global financial crisis. Also, the ratio of net loans to assets of foreign parent institutions of the Polish affiliates (parent_Net_Loas_to_Assets) has a positive influence on the profitability of a bank operating in Poland. This means that disintermediation tendencies in European banks have a negative effect on the profitability of their affiliates. The negative effect of the parent total capital ratio (parent_Total_Capital_Ratio) may mean that a higher capital ratio on average did not prevent higher profitability. This result is also relevant to the current economic policy debate about future regulatory requirements for the banking sector. Also, the $\mathrm{ROA}$ ratio of foreign parent institutions of Polish affiliates (parent_ROA) is insignificant in this model. However, in estimation 3 (during the Eurozone crisis of 2011-2012), most of the variables were insignificant.

Generally speaking, the results of the above estimations determined that the economic situation of international parent banks had an effect on the profitability of the Polish subsidiaries and branches of these banks during the global financial crisis. Those results may also support the fact that the geographical diversity of parent institutions helped the local financial system to remain relatively vigorous throughout the global financial crisis (Pawłowska et al., 2015).

\section{Conclusions}

The global financial crisis has resulted in a massive reduction in profitability for many banks in the EU. However, Poland experienced only a slight decrease in the profitability of its banking sector in the first part of the crisis (in 2009). After this, the profitability of the Polish banks increased. Generally, the results of comprehensive analyses concerning the profitability of Polish banks has confirmed the RMP hypothesis. On the one hand, this paper demonstrates a positive correlation between profitability and market structure and a positive and significant correlation between profitability and market power and also with the size of the bank.

Of the microeconomic control variables, we found that the core capital ratio has a significantly negative influence on bank profitability. Furthermore, the findings indicate that foreign currency loans did not positively contribute to bank profitability. We also found a positive correlation between intermediation (i.e., grater loans in total assets) and bank profitability. These results may show that business models based on strong lending positions were a stabilizing factor in the current financial crisis. Based on the Bankscope database, this paper found that disintermediation tendencies in European banks have a negative effect on the profitability of their affiliates. However, this paper found a negative coefficient between the ratio of total deposits to total assets and profitability.

The results show that foreign capital was a stabilizing mechanism during the entire period 
analyzed. However, this paper found a destabilizing impact of foreign banks during the first part of the crisis. This paper found a positive correlation between the context of parent banks and the profitability of their affiliates for entire period of analysis. These results are in line with the paper by Pawłowska et al. (2015) concerning the intragroup links between banking institutions after the Lehman Brothers failure, and they confirm these links in the context of the profitability of parent banks.

Finally, as in other countries, bank profitability is strongly influenced by cyclical developments, and this paper found a positive correlation between GDP growth and bank profit - the same effect was found for CPI indices. Finally, this paper found a positive correlation between GDP growth in the parent country and the profit of their affiliates in Poland.

\section{References}

Albertazzi, U. and Gambacorta, L. (2009). Bank profitability and the business cycle. Journal of Financial Stability, 5(4):393-409.

Arellano, M. and Bond, S. (1991). Some tests of specification for panel data: Monte Carlo evidence and an application to employment equations. The Review of Economic Studies, 58(2):277-297.

Arellano, M. and Bover, O. (1995). Another look at the instrumental variable estimation of error-components models. Journal of Econometrics, 68(1):29-51.

Athanasoglou, P. P., Brissimis, S. N., and Delis, M. D. (2008). Bank-specific, industry-specific and macroeconomic determinants of bank profitability. Journal of International Financial Markets, Institutions and Money, 18(2):121-136.

Bain, J. S. (1951). Relation of profit rate to industry concentration: American manufacturing, 1936-1940. The Quarterly Journal of Economics, pages 293-324.

Berger, A. N. (1995). The profit-structure relationship in banking-tests of market-power and efficient-structure hypotheses. Journal of Money, Credit and Banking, 27(2):404-431.

Bijlsma, M. and Zwart, G. T. J. (2013). The changing landscape of financial markets in Europe, the United States and Japan. Working Paper 774, Bruegel.

Bikker, J. A. and Hu, H. (2002). Cyclical patterns in profits, provisioning and lending of banks and procyclicality of the new Basel capital requirements. Banca Nazionale del Lavoro Quarterly Review, 55(221):143.

Bikker, J. A. and van Leuvensteijn, M. (2014). A New Measure of Competition in the Financial Industry: The Performance-conduct-structure Indicator, volume 83. Routledge. 
Blundell, R. and Bond, S. (1998). Initial conditions and moment restrictions in dynamic panel data models. Journal of Econometrics, 87(1):115-143.

Bond, S. and Windmeijer, F. (2002). Finite sample inference for GMM estimators in linear panel data models. CeMMAP Working Paper CWP04/02, Centre for Microdata Methods and Practice, Institute for Fiscal Studies.

Bond, S. R. (2002). Dynamic panel data models: a guide to micro data methods and practice. Portuguese Economic Journal, 1(2):141-162.

Cetorelli, N. (2004). Real Effects of Bank Competition. Journal of Money, Credit and Banking, 36(3):543-58.

Chen, S.-H. and Liao, C.-C. (2011). Are foreign banks more profitable than domestic banks? Home-and host-country effects of banking market structure, governance, and supervision. Journal of Banking and Finance, 35(4):819-839.

Claeys, S. and Vander Vennet, R. (2008). Determinants of bank interest margins in Central and Eastern Europe: A comparison with the West. Economic Systems, 32(2):197-216.

Degryse, H. and Ongena, S. (2008). Competition and regulation in the banking sector: a review of the empirical evidence on the sources of bank rents. Handbook of Financial Intermediation and Banking, 2008:483-554.

Delis, M., Kokas, S., and Ongena, S. (2014). Foreign ownership and market power in banking: Evidence from a world sample. mimeo, University of Cyprus Department of Economics.

Demirgüç-Kunt, A. and Huizinga, H. (2000). Financial Structure and Bank Profitability. World Bank Policy Research Working Paper 2430, World Bank, Washington.

Demsetz, H. (1973). Industry structure, market rivalry, and public policy. The Journal of Law and Economics, 16(1):1-9.

Goddard, J., Molyneux, P., and Wilson, J. O. (2004). The profitability of European banks: a cross-sectional and dynamic panel analysis. The Manchester School, 72(3):363-381.

Havrylchyk, O. and Jurzyk, E. (2011). Profitability of foreign banks in Central and Eastern Europe. Economics of Transition, 19(3):443-472.

Hicks, J. R. (1935). Annual Survey of Economic Theory: The Theory of Monopoly. Econometrica, 3(1):1-20.

La Porta, R., Lopez-de Silanes, F., and Shleifer, A. (2002). Government ownership of banks. The Journal of Finance, 57(1):265-301. 
Maudos, J. and De Guevara, J. F. (2004). Factors explaining the interest margin in the banking sectors of the European Union. Journal of Banking and Finance, 28(9):22592281.

Mirzaei, A., Moore, T., and Liu, G. (2013). Does market structure matter on banks' profitability and stability? Emerging vs. advanced economies. Journal of Banking and Finance, $37(8): 2920-2937$.

Molyneux, P. and Thornton, J. (1992). Determinants of European bank profitability: A note. Journal of Banking and Finance, 16(6):1173-1178.

National Bank of Poland (2004). Financial System Development Report. Warsaw.

Pawłowska, M., Serwa, D., and Zajączkowski, S. (2015). International Banking and Liquidity Risk Transmission: Evidence from Poland. IMF Economic Review, 63(3):585-605.

Polish Financial Supervision Authority (2010). Report on the condition of Polish banks in 2009. Warsaw.

Polish Financial Supervision Authority (2013). Report on the condition of Polish banks in 2012. Warsaw.

Rumler, F. and Waschiczek, W. (2010). The Impact of Economic Factors on Bank Profits. Monetary Policy and the Economy, (4):49-67.

Smirlock, M. (1985). Evidence on the (non) relationship between concentration and profitability in banking. Journal of Money, Credit and Banking, 17(1):69-83.

van Horen, N. and Claessens, S. (2012). Foreign Banks; Trends, Impact and Financial Stability. IMF Working Papers 12/10, International Monetary Fund.

Windmeijer, F. (2005). A finite sample correction for the variance of linear efficient two-step GMM estimators. Journal of Econometrics, 126(1):25-51. 
Figure 1: Share of foreign investors (in assets) in the Polish banking sector

— Banks with majority of Polish ownership

—Banks with majority foreign equity

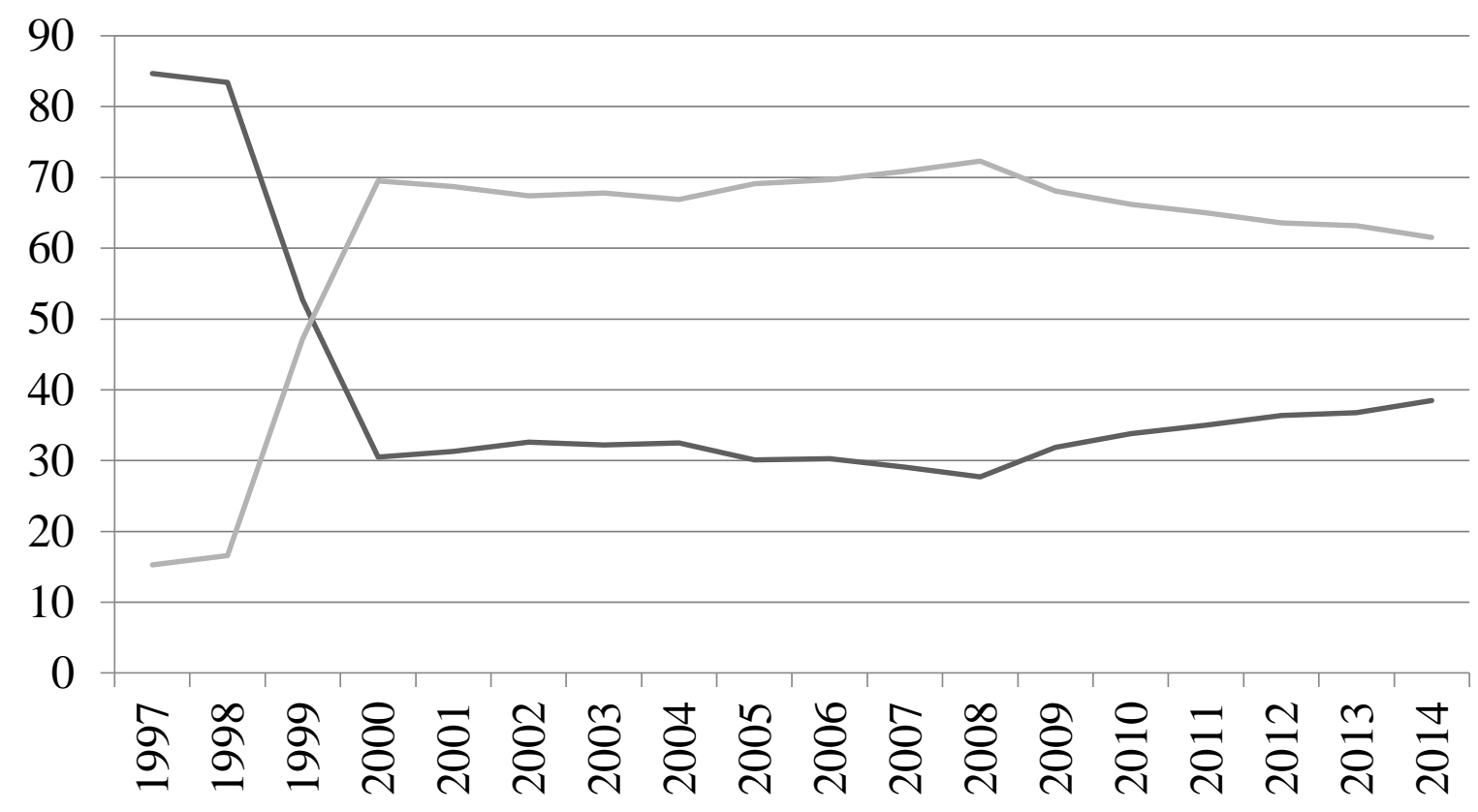

Source: Polish Financial Supervision Authority. 
Figure 2: Share of foreign investors in assets of the Polish banking sector by country of origin

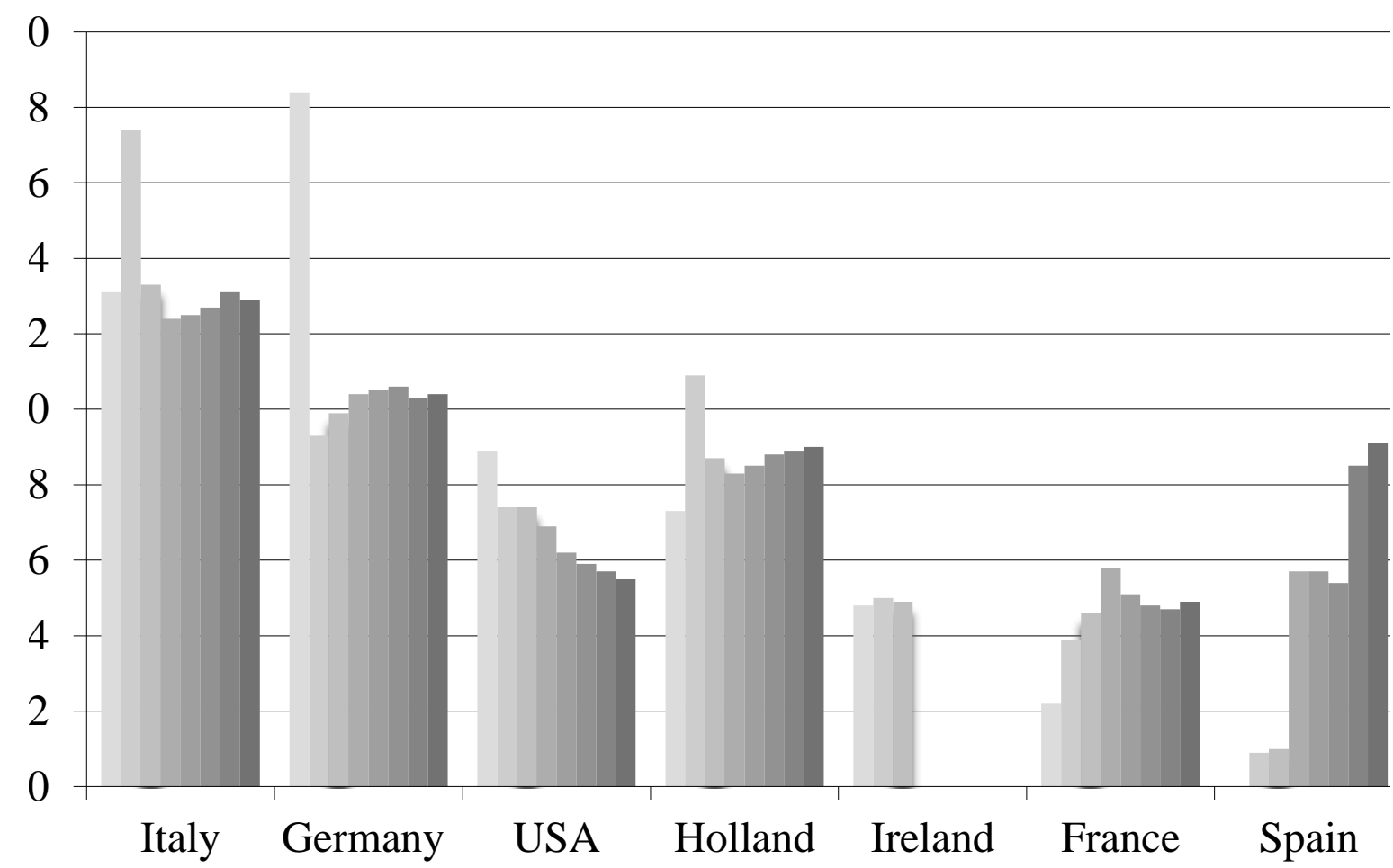

Source: Polish Financial Supervision Authority. 
Figure 3: Herfindahl-Hirschman indices (quarterly)

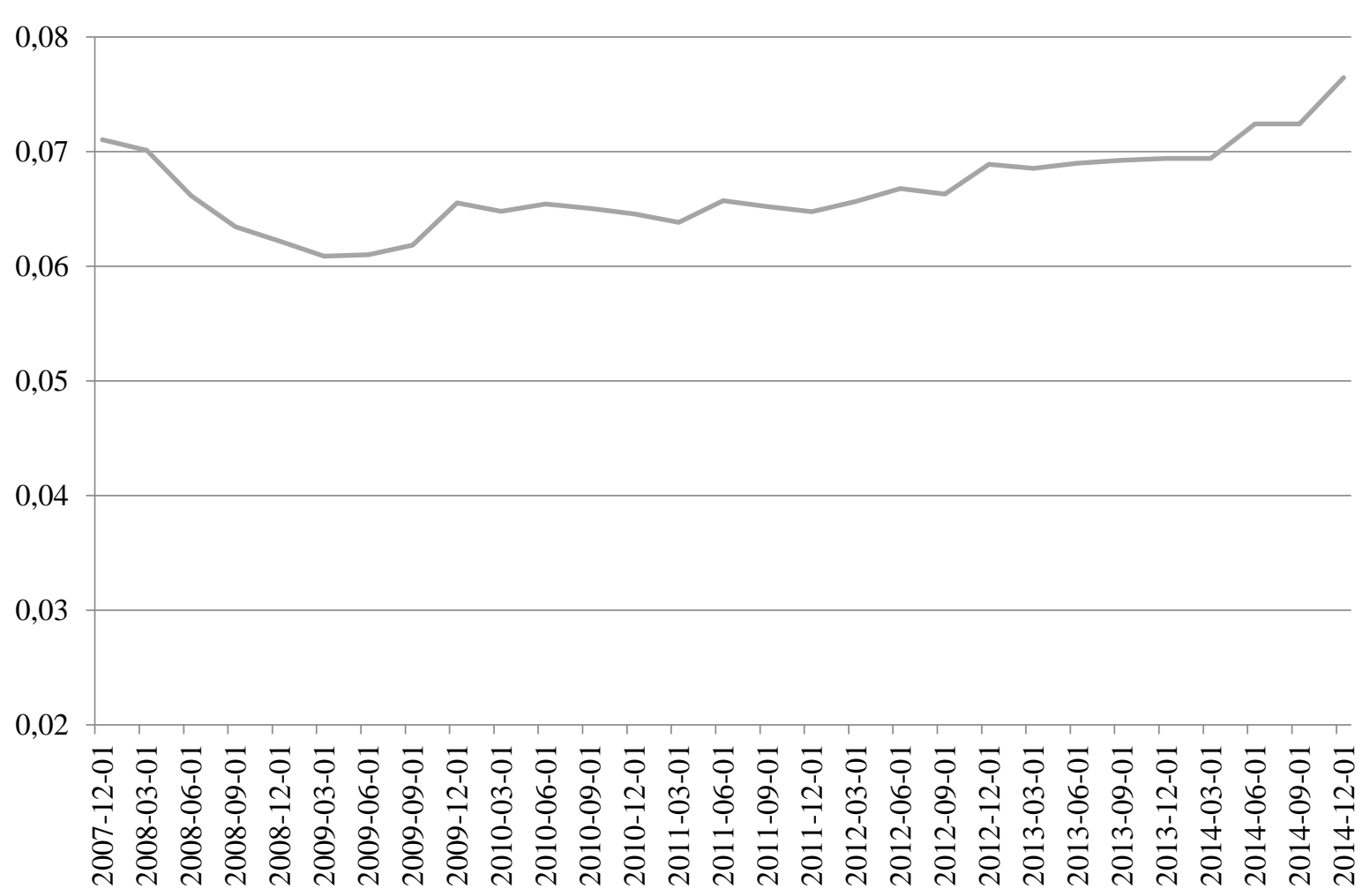

Source: NBP and author's calculations. HHI index was seasonally adjusted. 
Figure 4: GDP growth and inflation rate (yoy quarterly) (\%)

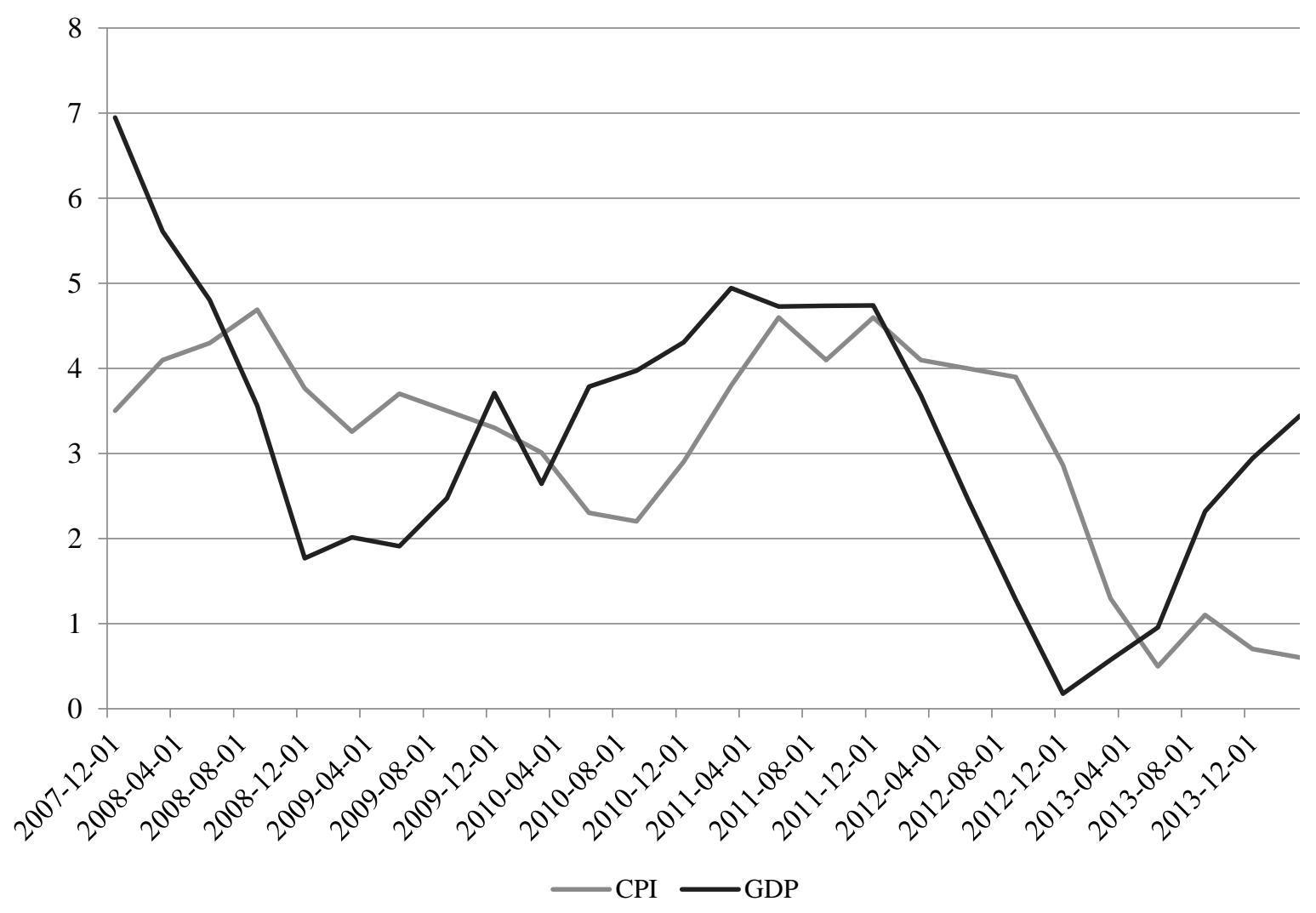

Source: NBP and author's calculations. 
Figure 5: Profitability ratio in EU (ROA, in \%)

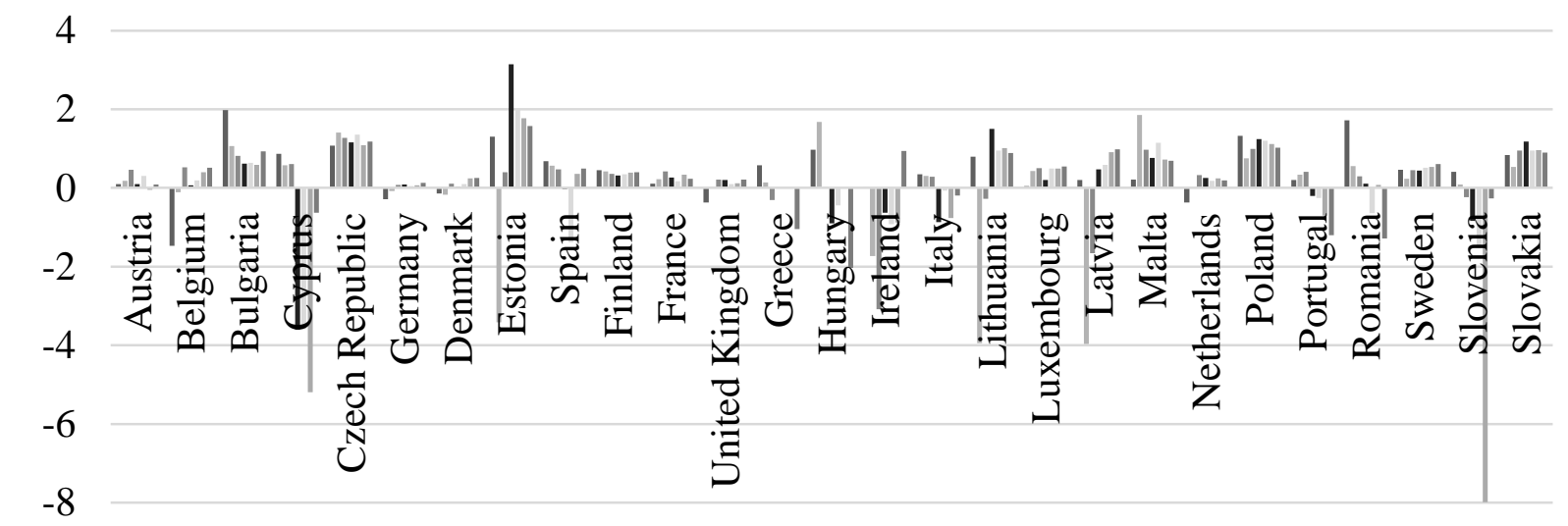

Source: European Central Bank.

Figure 6: Profitability ratio in EU (ROE, in \%)

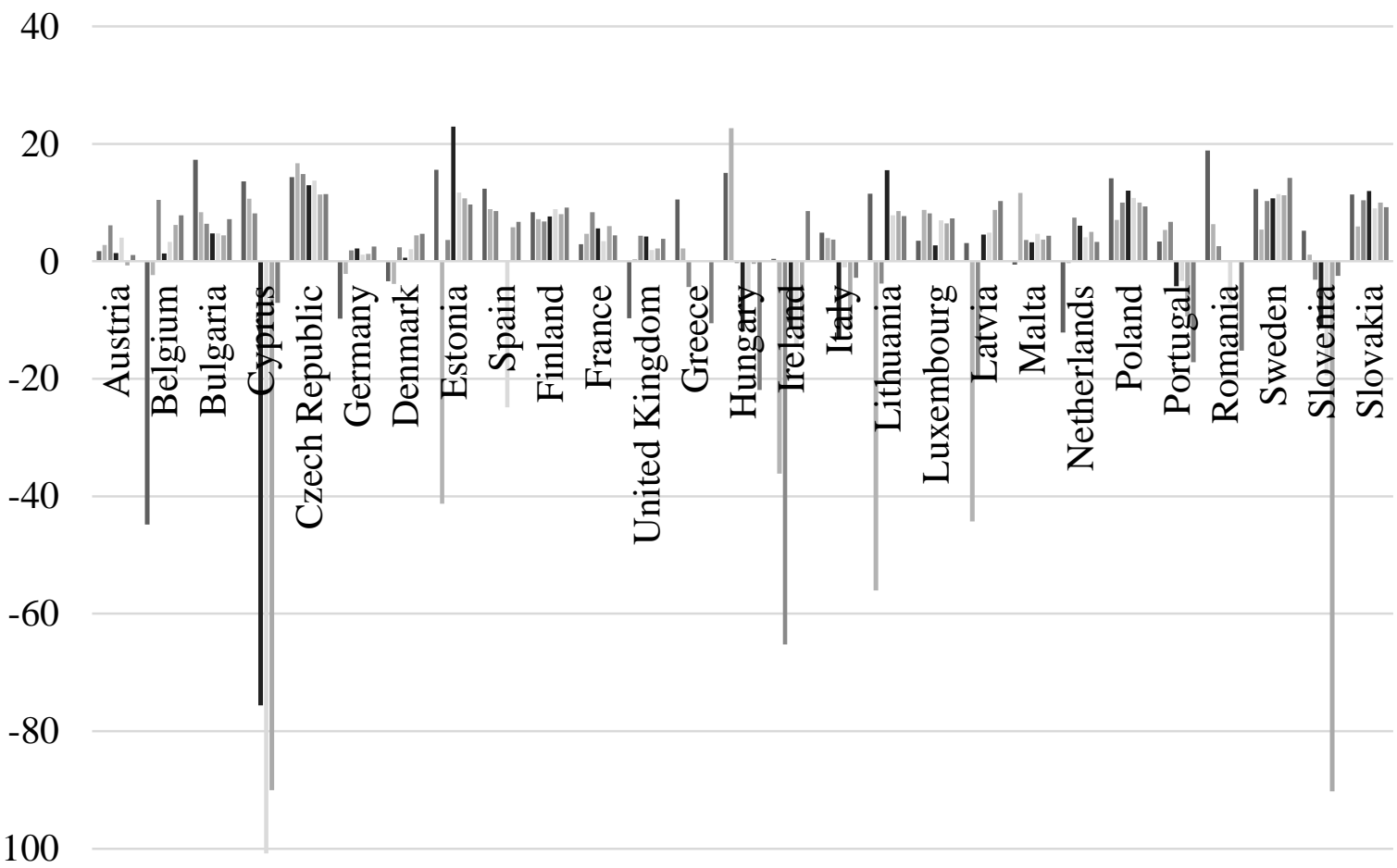

Source: European Central Bank. 
Figure 7: Assets of the Polish banking sector [in bn PLN]

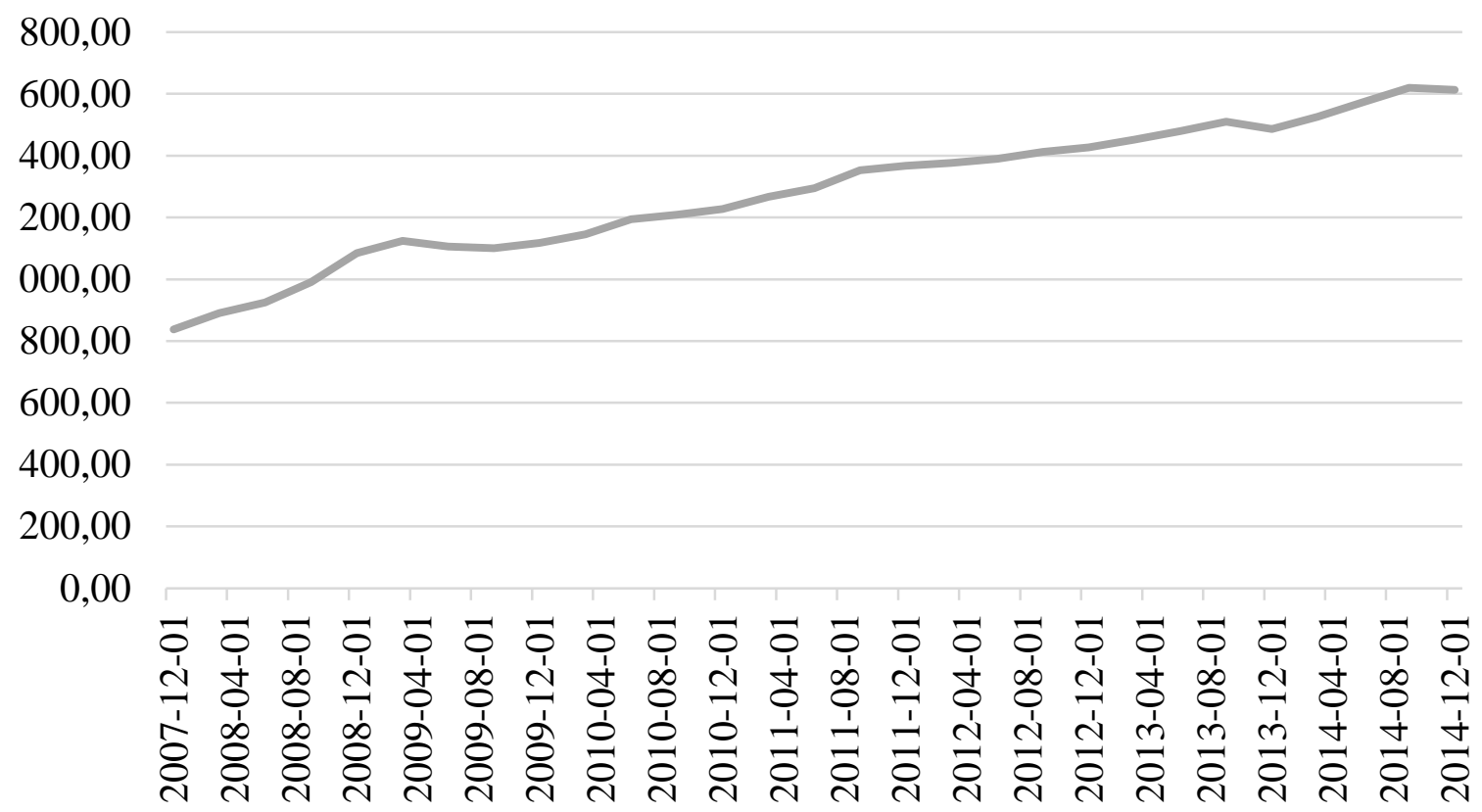

Source: Polish Financial Supervision Authority.

Figure 8: Loans for nonfinancial sector and housing loans of the Polish banking sector [in bn PLN]

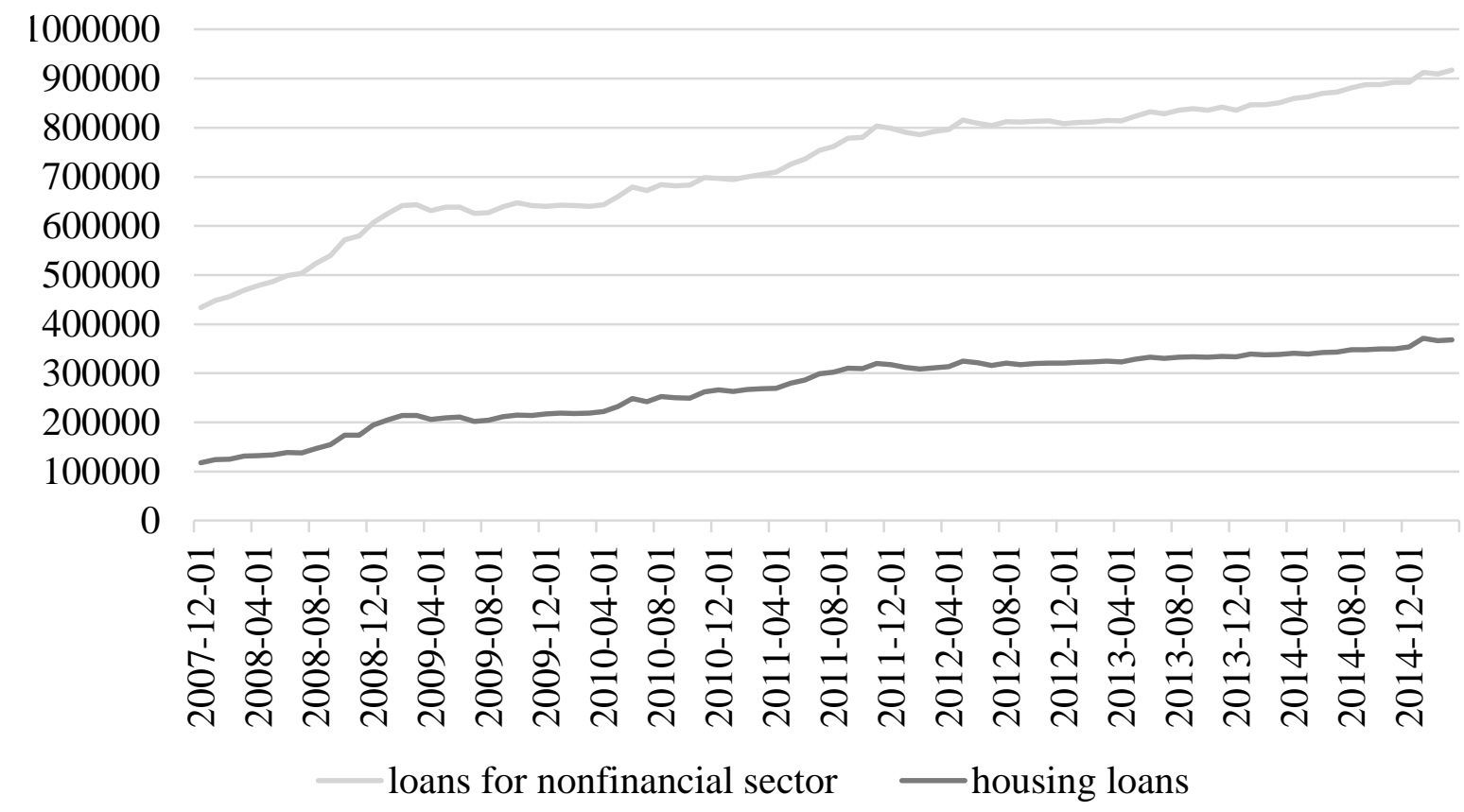

Source: National Bank of Poland. 
Table 1: Summary Statistics on Bank Characteristics (quarterly data)

1. Data for all samples. Source: Author's calculations on the basis of NBP and CSO data.

\begin{tabular}{|c|c|c|c|c|c|c|c|c|}
\hline & \multicolumn{4}{|l|}{ All Banks } & \multicolumn{4}{|c|}{$\begin{array}{l}\text { Banks with Majority of Foreign } \\
\text { capital }\end{array}$} \\
\hline & Mean & SD & Min & $\operatorname{Max}$ & Mean & SD & Min & $\operatorname{Max}$ \\
\hline Observations & \multicolumn{4}{|l|}{1634} & \multicolumn{4}{|l|}{1407} \\
\hline \multicolumn{9}{|c|}{ Dependent Variables: } \\
\hline \multicolumn{9}{|c|}{ Balance Sheet Data (for each bank $i$ and quarter $t$ ) } \\
\hline ROA Ratio(\%) & -0.0246 & 0.20185 & -2.86388 & 0.81991 & -0.0279 & 0.2178 & -2.8639 & 0.8199 \\
\hline ROE Ratio(\%) & 0.020114 & 0.20185 & -4.731094 & 0.48876 & 0.01802 & 0.21173 & -4.7311 & 0.4047 \\
\hline \multicolumn{9}{|c|}{ Independent Variables: } \\
\hline \multicolumn{9}{|c|}{ Balance Sheet Data for Each Quarter $t$} \\
\hline \multicolumn{9}{|c|}{ Market Structure } \\
\hline \multicolumn{9}{|c|}{ Balance sheet data for each quarter $t$} \\
\hline HHI & 0.059575 & 0.002153 & 0.05599 & 0.06412 & 0.05957 & 0.00215 & 0.05599 & 0.06413 \\
\hline $\begin{array}{l}\text { Log of Size of Bank- } \\
\text { ing Sector }\end{array}$ & 27.68921 & 0.158017 & 27.3304 & 27.8992 & 27.6892 & 0.15798 & 27.3305 & 27.8992 \\
\hline \multicolumn{9}{|c|}{ Market Power } \\
\hline \multicolumn{9}{|c|}{ Balance Sheet Data (for each bank $i$ and quarter $t$ ) } \\
\hline MP Ratio (\%) & 0.014539 & 0.027114 & $1.42 \mathrm{e}-1$ & 0.16214 & 0.01236 & 0.022408 & $1.42 \mathrm{e}-1$ & 0.16213 \\
\hline ML Ratio (\%) & 0.014539 & 0.027267 & 0 & 0.17197 & 0.01230 & 0.021413 & 0 & 0.15757 \\
\hline Log of Assets (size) & 21.69478 & 2.438546 & 12.0695 & 26.0074 & 21.4947 & 2.492519 & 12.0694 & 25.7244 \\
\hline \multicolumn{9}{|c|}{ Bank-Specific Variables } \\
\hline \multicolumn{9}{|c|}{ Balance Sheet Data (for each bank $i$ and quarter $t$ ) } \\
\hline Tier1 Ratio (\%) & 0.182737 & 0.165391 & 0.0054 & 3.14585 & 0.17869 & 0.161253 & 0.00538 & 3.14584 \\
\hline $\begin{array}{l}\text { Total Loans/Assets } \\
(\%)\end{array}$ & 0.777339 & 0.225674 & 0 & 1.47161 & 0.79578 & 0.227887 & 0 & 1.47160 \\
\hline $\begin{array}{l}\text { Total Deposit / } \\
\text { Assets (\%) }\end{array}$ & 0.346451 & 0.338144 & 0 & 2.52977 & 0.3411 & 0.330231 & 0 & 2.52977 \\
\hline $\begin{array}{l}\text { FX Housing Loans } \\
\text { / Assets }(\%)\end{array}$ & 0.085851 & 0.152134 & 0 & 0.65490 & 0.08676 & 0.1559 & 0 & 0.65490 \\
\hline \multicolumn{9}{|c|}{ Macroeconomics } \\
\hline \multicolumn{9}{|c|}{ Data for Each Quarter $t$} \\
\hline GDP & 3.278261 & 1.75493 & 0.2 & 6.9 & 3.27721 & 1.75502 & 0.2 & 6.9 \\
\hline$\overline{\mathrm{CPI}}$ & 3.408696 & 1.02258 & 0.5 & 4.7 & 3.40863 & 1.02233 & 0.5 & 4.7 \\
\hline
\end{tabular}

2. Data for Parent Banks (quarterly data). Source: Author's calculations on the basis of Bankscope and Eurostat data.

\begin{tabular}{|c|c|c|c|c|}
\hline & Mean & SD & Min & Max \\
\hline Observations & \multicolumn{4}{|l|}{1257} \\
\hline \multicolumn{5}{|l|}{$\begin{array}{l}\text { Independent Vari- } \\
\text { ables: }\end{array}$} \\
\hline parent Net Loans/Assets (\%) & 52.27033 & 23.10678 & 0.005 & 99.251 \\
\hline parent_Total_Capital_Ratio (\%) & 14.16492 & 5.224161 & 7 & 56.6 \\
\hline parent_ROA (\%) & 0.477185 & 0.866871 & -6.36 & 8.958 \\
\hline parent_ROE (\%) & 6.934040 & 9.598102 & -129.584 & 42.196 \\
\hline parent_Loan_Loss_Ratio (\%) & 2.734991 & 1.982544 & 0.021 & 12.44 \\
\hline parent_GDP & 0.1164969 & 2.770955 & -9.2 & 7.9 \\
\hline
\end{tabular}

Note: This table provides summary statistics (mean and standard deviation for bank balance sheets data and macroeconomics data). Data are observed quarterly 2007Q4-2013Q2. 
Table 2: Spearman's Rank Correlation Coefficients for all Variables

\begin{tabular}{|l|l|l|l|l|l|l|l|l|l|l|l|}
\hline & ROA & MP & MPL & LA & HHI & LTA & DEP & Tier1 & FXH & Size & GDP \\
\hline ROA & 1 & & & & & & & & & & \\
\hline MP & 0.0123 & 1 & & & & & & & & & \\
\hline MPL & 0.0016 & $0.9797^{*}$ & 1 & & & & & & & & \\
\hline LA & 0.0183 & $0.9979^{*}$ & $0.9762^{*}$ & 1 & & & & & & & \\
\hline HHI & $0.1035^{*}$ & -0.0022 & -0.02 & 0.0404 & 1 & & & & & & \\
\hline LTA & $0.1549^{*}$ & $-0.398^{*}$ & $-0.26^{*}$ & $-0.401^{*}$ & -0.03 & 1 & & & & & \\
\hline DEP & -0.0742 & $0.2865^{*}$ & $0.1699^{*}$ & $0.2946^{*}$ & 0.0918 & $-0.752^{*}$ & 1 & & & & \\
\hline Tier1 & $0.3373^{*}$ & $-0.516^{*}$ & $-0.569^{*}$ & $-0.508^{*}$ & $0.1660^{*}$ & 0.0307 & 0.0057 & 1 & & & \\
\hline FXH & $-0.114^{*}$ & $0.7254^{*}$ & $0.7780^{*}$ & $0.7260^{*}$ & 0.0200 & 0.0844 & $-0.15^{*}$ & $-0.59^{*}$ & 1 & & \\
\hline Size & $0.1731^{*}$ & 0.0023 & -0.017 & 0.0580 & $0.7752^{*}$ & -0.0269 & $0.1115^{*}$ & $0.163^{*}$ & 0.0319 & 1 & \\
\hline GDP & -0.0110 & -0.0112 & -0.024 & -0.0203 & $-0.193^{*}$ & -0.0142 & 0.0253 & 0.0051 & -0.006 & $-0.18^{*}$ & 1 \\
\hline CPI & 0.0230 & 0.0050 & -0.000 & 0.0104 & $-0.235^{*}$ & 0.0392 & -0.016 & $-0.10^{*}$ & 0.0200 & -0.003 & $0.4511^{*}$ \\
\hline
\end{tabular}

Source: Author's calculations on the basis of NBP and CSO data. */ indicates significance at the $10 \%$ level.

Table 3: Spearman's Rank Correlation coefficients for Variables for Parent Banks

\begin{tabular}{|l|l|l|l|l|l|l|}
\hline Data for Parent Banks & ROA $_{f}$ & $\begin{array}{l}\text { Parent } \\
\text { Total_Capital_Ratio }\end{array}$ & $\begin{array}{l}\text { Parent } \\
\text { GDP }\end{array}$ & $\begin{array}{l}\text { Parent } \\
\text { ROA }\end{array}$ & $\begin{array}{l}\text { Parent } \\
\text { CTI }\end{array}$ & $\begin{array}{l}\text { Parent } \\
\text { NetLoans/Assets }\end{array}$ \\
\hline ROA $_{f}$ & 1 & & & & & \\
\hline parent_Total_CapitaLRatio & $0.1142^{*}$ & 1 & & & & \\
\hline parent_GDP & $0.0962^{*}$ & $0.2395^{*}$ & 1 & & & \\
\hline parent_ROA & -0.0381 & 0.0329 & $0.2724^{*}$ & 1 & & \\
\hline parent_CTI & 0.0268 & $0.2214^{*}$ & 0.0349 & $-0.5506^{*}$ & 1 & \\
\hline parent_NetLoans/Assets & -0.0056 & -0.0734 & $-0.1615^{*}$ & $0.3737^{*}$ & $-0.6019^{*}$ & 1 \\
\hline
\end{tabular}

Source: Author's calculations on the basis of Bankscope and Eurostat data. */ indicates significance at the $10 \%$ level. 
Table 4: Empirical Results for Baseline Model

\begin{tabular}{|c|c|c|c|c|c|}
\hline Variables & Estimate 1 & Estimate 2 & Estimate 3 & Estimate 4 & Estimate 5 \\
\hline L1.ROA & $0.7359047^{* * *}$ & $0.7206154^{* * *}$ & $0.614576^{* * *}$ & $0.613027^{* * *}$ & $0.576682^{* * *}$ \\
\hline \multicolumn{6}{|c|}{ Market Structure } \\
\hline HHI & & -4.994079 & $0.9480281^{* *}$ & 1.595917 & -3.900502 \\
\hline Size & $0.257475^{* *}$ & - & - & - & - \\
\hline \multicolumn{6}{|l|}{ Market Power } \\
\hline$M P$ & - & $11.18935^{*}$ & - & - & - \\
\hline$M L$ & 1.017407 & - & -0.0036206 & - & - \\
\hline$L A$ & - & - & - & $0.058173^{* * *}$ & $0.053436^{* * *}$ \\
\hline \multicolumn{6}{|c|}{ Foreign Ownership } \\
\hline$F O$ & -0.0434477 & 0.0362766 & -0.0019722 & $0.1282207^{* *}$ & $0.372938^{* *}$ \\
\hline$F O \times C R I$ & -0.0138528 & -0.004424 & $-0.010934 *$ & $-0.0012158^{*}$ & - \\
\hline$F O \times E u D C R I$ & - & - & - & & $0.0204672^{*}$ \\
\hline \multicolumn{6}{|c|}{ Macroeconomics } \\
\hline$G D P$ & - & $0.010461^{*}$ & - & - & $0.0028546^{* *}$ \\
\hline$C P I$ & -0.0016897 & - & $0.000649^{* *}$ & $0.0496^{* *}$ & - \\
\hline \multicolumn{6}{|c|}{ Bank-Specific Variables } \\
\hline LTA & - & $0.2678998^{* * *}$ & - & $0.058534^{* *}$ & $0.2293875^{*}$ \\
\hline$D T A$ & $-0.0377529^{* * *}$ & & $-0.0374935^{*}$ & - & - \\
\hline$C A R$ & - & - & $-0.001551^{* * *}$ & - & - \\
\hline$F X H L$ & - & -1.508736 & - & $-0.780618^{* *}$ & $-0.752328^{* *}$ \\
\hline const & $-6.80247^{*}$ & -0.1833865 & -0.0270513 & -0.0270513 & -1.35171 \\
\hline Hansen Test & 0.974 & 0.824 & 0.961 & 0.974 & 0.661 \\
\hline $\mathrm{AR}(1)$ & 0.097 & 0.326 & 0.084 & 0.061 & 0.048 \\
\hline $\operatorname{AR}(2)$ & 0.196 & 0.426 & 0.196 & 0.343 & 0.330 \\
\hline Time Period & \multicolumn{5}{|c|}{ 2007Q4-2013Q2 } \\
\hline $\begin{array}{l}\text { Number of } \\
\text { observations }\end{array}$ & 1231 & 1231 & 1231 & 1231 & 1231 \\
\hline Number of gr. & 86 & 86 & 86 & 86 & 86 \\
\hline
\end{tabular}

Source: Author's calculations. $* * * / * * / *$ indicate significance at the $1 \% / 5 \% / 10 \%$ levels respectively. All variables were seasonally adjusted. AR(1) - Arellano-Bond test for AR(1) in first differences. $\operatorname{AR}(2)$ - Arellano-Bond test for $\operatorname{AR}(2)$ in first differences. Hansen Test the test for over-identifying restrictions in GMM dynamic model estimation. 
Table 5: Effect of Situation in Parent Banks on Profitability of Foreign Banks in Poland

\begin{tabular}{|c|c|c|c|}
\hline Time Period: & 2007Q4-2013Q2 & $\begin{array}{l}\text { Global Financial } \\
\text { Crisis }\end{array}$ & $\begin{array}{l}\text { the Eurozone Cri- } \\
\text { sis }\end{array}$ \\
\hline & Estimate 1 & Estimate 2 & Estimate 3 \\
\hline L1.ROAf & $0.8503813^{* * *}$ & $0.7812995^{* * *}$ & $0.7018803^{* * *}$ \\
\hline \multicolumn{4}{|c|}{ Macroeconomics - Business Cycle in Parent Country } \\
\hline parent_GDP & $0.009222^{*}$ & $0.008008^{* *}$ & 0.0119602 \\
\hline \multicolumn{4}{|c|}{ Bank-Specific Variables in Parent Country } \\
\hline parent_Total_Capital_Ratio & $-0.0061702^{*}$ & 0.0137249 & -0.0009048 \\
\hline parent_Net_Loas_to_Assets & $0.0025147^{* * *}$ & $0.0121431^{* * *}$ & 0.002245 \\
\hline parent_ROA & 0.0067614 & 0.0259831 & 0.0461367 \\
\hline const & -0.2597817 & $-0.4994779 * *$ & 0.046968 \\
\hline Hansen Test & 0.638 & 0.253 & 0.974 \\
\hline $\mathrm{AR}(1)$ & 0.097 & 0.218 & 0.071 \\
\hline $\operatorname{AR}(2)$ & 0.196 & 0.554 & 0.171 \\
\hline Time Period & 2007Q4-2013Q2 & 2008Q1-2010Q1 & 2010Q2-2013Q2 \\
\hline Number of Observations & 710 & 321 & 389 \\
\hline Number of groups & 51 & 45 & 46 \\
\hline
\end{tabular}

Source: Author's calculations. $* * * / * * / *$ indicate significance at the $1 \% / 5 \% / 10 \%$ levels respectively. AR(1) - Arellano-Bond test for $\mathrm{AR}(1)$ in first differences. AR(2) - Arellano-Bond test for $\operatorname{AR}(2)$ in first differences. Hansen Test - the test for over-identifying restrictions in GMM dynamic model estimation. 